\title{
Wild bumble bee foraging preferences and fat content in highbush blueberry agro-ecosystems
}

\author{
Michelle TOSHACK, Elizabeth ELLE \\ Evolutionary and Behavioural Ecology Research Group, Department of Biological Sciences, Simon Fraser University, \\ Burnaby, BC V5A 1S6, Canada
}

Received 27 August 2018 - Revised 25 March 2019 - Accepted 26 April 2019

\begin{abstract}
Agricultural intensification can impact the availability and quality of resources. We analyzed resource use by bumble bees (Bombus spp.), important pollinators of highbush blueberry (Vaccinium corymbosum), collected from conventional highbush blueberry farms, organic highbush blueberry farms, and nearby natural areas in the lower Fraser River valley of British Columbia, Canada. We identified corbicular pollen and measured bee fat content as an indicator of body condition. Bumble bees use non-crop resources, including pollen from plant species not found on farms. Bees from natural areas had higher pollen protein content in corbicular pollen and higher body fat content than those from conventional and organic farms. There was no difference between farm types, and we could not demonstrate a relationship between pollen protein and bee fat content. Our findings illustrate the importance of resource availability throughout agro-ecological landscapes, including not only farms but also offfarm areas.
\end{abstract}

\section{Bombu s / pollen analysis / pollinator body condition / Vaccinium corymbosum}

\section{INTRODUCTION}

Intensification of agriculture and associated landuse change is a major cause of habitat loss and fragmentation globally (Tilman et al. 2001; Defries et al. 2004; Foley et al. 2005), and habitat loss has led to declines of wild invertebrate pollinators within agricultural landscapes (Cunningham 2000; Aizen et al. 2002; Klein et al. 2002; Kremen et al. 2002; Steffan-Dewenter et al. 2002; Klein et al. 2003; Ricketts 2004). Although mass-blooming crops can provide pollen and nectar resources for pollinators, short crop bloom time reduces their benefit as minimal resources are available when crops are not

Electronic supplementary material The online version of this article (https://doi.org/10.1007/s13592-019-00654-3) contains supplementary material, which is available to authorized users.

Corresponding author: E. ELLE, eelle@sfu.ca Manuscript Editor: Monique Gauthier in bloom (Kremen et al. 2002; Westphal et al. 2003). Weedy species on farms offer alternative forage for pollinators (Morandin and Winston 2005), and they may additionally forage off-farm. Bees have been shown to collect off-farm pollen resources to provision on-farm nests (Bobiwash et al. 2018) and to forage in rural landscapes with higher resource diversity compared to farms (Couvillon et al. 2014). Such foraging decisions can have implications for the crops that rely on bees for pollination (WaltherHellwig and Frankl 2000) and should also be related to the nutritional status of bees (Naug 2009).

Pollen is an important component of bee nutrition, but it is known to vary in protein content (2.5-61\%, Roulston and Cane 2000), lipid composition, vitamin/mineral content, and amino acid composition (Goulson et al. 2015). Bees rely exclusively on pollen for protein to feed developing larvae (Haydak 1970), and bumble bees have been shown to prefer pollen with higher protein content (Leonhardt and Blüthgen 2012; Somme et al. 
2014; Vaudo et al. 2016). Pollen that contains less than $20 \%$ crude protein content is considered a low-quality pollen for honey bee colony fitness (Somerville 2005), and bumble bees select higherprotein pollen sources than honey bees (Leonhardt and Blüthgen 2012). Using the conservative $20 \%$ as a benchmark, low protein pollen is present in some pollinator-dependent crops, like sunflower (Nicolson and Human 2013), blueberry, and buckwheat (Somerville 2005), likely impacting their pollination. Central-place foraging bees with nests in or near these low-protein crops will need to forage off-farm to meet their protein needs. Of course, other aspects of the nutrient complement of pollen are also important (e.g., Vanderplanck et al. 2014; Moerman et al. 2016), but, here, we focus on using crude protein content values from the existing literature to assess foraging preferences of wild bumble bees collected on farms and in natural areas within agricultural landscapes.

The type and range of available floral resources may affect bee body condition and health, although this has rarely been studied in wild bees (Goulson et al. 2015; Vaudo et al. 2016). The fat body in insects synthesizes and accumulates lipid reserves as well as carbohydrates, amino acids, and other metabolites (Arrese and Soulages 2010). Because fat bodies store and utilize energy, detoxify waste products (Arrese and Soulages 2010), synthesize immunoproteins (Amdam and Omholt 2002), and can be considered an indirect proxy for immunocompetence (Wilson-Rich et al. 2009; Alaux et al. 2010), fat content is a realistic indicator of body condition in bees. In this study, we use fat content as a metric to measure body condition of individual bees; colony-level metrics were not feasible because wild bumble bee nests are challenging to locate.

Differences in farm management, for example, conventional vs. organic, may impact foraging choices and wild bee nutrition. Organic farms typically have smaller field sizes (and therefore more edge habitat with available resources) and grow more diverse crops (Norton et al. 2009). This may provide a range of nutritional options over a longer temporal scale than is typical for conventional farms (Gabriel et al. 2013). In addition, the amount of non-crop floral resources can be higher on organic farms (Morandin and Winston 2005). Few studies have examined how farm type affects wild bee nutrition and body condition.

We ask the following questions:

1. Which pollen types do wild bumble bees collect for nest provisioning, and is this different from the resources available on the farm?

2. Are there differences in pollen collected by bees found on different site types within agricultural landscapes, and is this related to protein content of pollen?

3. Does pollen diversity or protein content of pollen affect the fat content of bumble bees foraging in different site types?

We hypothesized that bumble bees would tend to collect higher-protein pollens from those available to provision their nests, though foraging choices are likely to reflect the pollen sources available in location where bees are foraging. We expected diversity of pollen sources to be highest in natural areas and lowest on conventional farms, and that body condition (fat content) would also be highest in natural areas and lowest on conventional farms, with organic farms intermediate for both pollen diversity and bee body condition. We controlled for bee body size (as measured by inter-tegular span) because it is expected to affect foraging range (Greenleaf et al. 2007) and total fat content in bees.

\section{MATERIALS AND METHODS}

\subsection{Study sites}

We used 18 sites distributed throughout the lower Fraser River valley, British Columbia: 6 conventionally grown blueberry farms, 6 organically grown blueberry farms, and 6 "natural" areas. We worked with highbush blueberry (Vaccinium corymbosum L.) because this massblooming crop is known to have low pollen protein content (13.9\%, Somerville 2001). This is below the $20 \%$ crude protein required to meet nutritional requirements of honey bees; honey bee colonies foraging on monocultures of lowbush blueberry (Vaccinium angustifolium) 
exhibit a reduction in brood rearing compared to non-Vaccinium fields in Québec (Girard et al. 2012). Similar impacts of low protein may be expected for bumble bees, especially since there is some evidence that they prefer higher pollen protein content than honey bees (Leonhardt and Blüthgen 2012). We considered different site types because management differences among farms are often related to differences in the availability of on-farm resources for bees (e.g., pollen from weeds), and weed cover is often higher on organic farms (Morandin and Winston 2005). The organic farms were either certified by an official certification body (Certified Organic Associations of B.C. or Canadian Food Inspection Agency) or followed organic practices by not using synthetic fertilizers or pesticides. We paired the conventional and organic farms as closely as possible for cultivar (paired within cultivar Bluecrop, Duke, Elliot, or Hardiblue), location, surrounding habitat, and farm size. Conventional farm sizes ranged from 2.0 to $22.5 \mathrm{ha}$, and organic farm sizes ranged from 0.9 to 28.1 ha. In our region, farms are largely surrounded by semi-natural land, blueberry farms, and other perennial agriculture (Toshack 2018). Our "natural" sites were largely secondgrowth forests with many flowering shrubs, managed by the Metro Vancouver Regional Parks or the City of Abbotsford. Natural areas were chosen to be near the paired farm sites $(<20 \mathrm{~km})$, and all sites were separated by at least $2 \mathrm{~km}$ to minimize the chance that floral visitors might move among sites.

\subsection{Floral resource quantification}

We conducted vegetation surveys five times, approximately weekly, to include the blueberry bloom and shortly after. We selected 10 survey points at stratified random intervals of $5 \mathrm{~m}$ along each of three transects. In the farms, the transects were located at the field edge, 25 and $50 \mathrm{~m}$ into the crop. In the natural areas, the transects were normally located along an edge or path. We used a $25-\mathrm{cm}$ by $2-\mathrm{m}$ quadrat perpendicular to the transect to quantify the percentage of flowers in bloom by species, including both ground vegetation and shrubs in our counts, and so including blueberry flowers on farms.

\subsection{Bumble bee resource use and body condition}

\subsubsection{Bee collection}

We focused on bumble bees (Bombus spp.) as these are the main wild pollinators of highbush blueberry in British Columbia (Button and Elle 2014). They are central-place foragers that nest on or underground, with typical colony sizes ranging from 50 to 200 individuals and development of new workers taking approximately two weeks (Goulson et al. 2001). In bees, fat content is determined by the resources fed to developing larvae, with adult fat content declining for the duration of the bee's life (O'Neill et al. 2015). Thus, we considered bees collected near to the middle or end of the blueberry bloom to have been likely fed from resources including blueberry. We net collected 256 worker bumble bees of the three most abundant species (Bombus mixtus, B. flavifrons, and $B$. melanopygus) over a 10 -day period in early May. Bees were collected when foraging on flowers, and although we cannot know if they foraged elsewhere before being net-collected, we assumed that their pollen loads represented resources available within our study sites or the nearby landscape. The collection period was restricted to a short time frame because bee lipid content fluctuates considerably throughout the season. Bees were stored at $-80{ }^{\circ} \mathrm{C}$ (after corbicular pollen was removed) until lipid analysis was conducted.

\subsubsection{Pollen identification}

We removed both corbicular pollen loads from each bee, suspended the pollen in $95 \%$ ethanol, vortexed the samples, and then pipetted a subsample onto a microscope slide following the methodology in Kearns and Inouye (1993). Fuchsine gelatin was added to the slide to dye the pollen grains for ease of identification. One observer counted and identified all pollen grains to reduce observer bias. Each pollen grain was identified to the lowest taxonomic level possible under $400 \times$ magnification, using a reference library from our laboratory, as well as Hodges (1952) and a pollen atlas (Crompton and Wojtas 1993). 
In most cases, the lowest taxonomic level possible for pollen identification is genus, and, in some cases, it is family. We counted 100 pollen grains along a randomly selected transect on the slide. In a sample of 256 bees, we included 17 slides that had between 51 and 100 grains (and analyzed as a proportion) but discarded any slides with a pollen count of $<50$ ( 12 slides) for a total of 244 bees. If any pollen type was observed only once, that count was excluded from further analysis as it may be due to contamination (Westrich and Schmidt 1986).

\subsubsection{Estimate of pollen protein collected per bee}

We compiled crude protein percentage for the pollen types identified in corbicular loads from published sources (Supplementary Material). Where the protein percentage had not been measured for a particular plant species, we used values from a congener or another member of the plant family if available (averaging across multiple congeners or family members where available), or in one case where there was no information even for the family (Geranaceae) we used the average crude protein across all plant species $(25 \%$, Somerville 2005). We recognize the limitations of this approach as chemical composition of pollen may vary within genera or families, but as many species have not been assessed, our method does provide a useful index for comparative purposes, and is conservative as it underestimates variation among species. We estimated the amount of total protein content per 100 pollen grains by multiplying the proportion of each pollen type collected by the crude protein content of that type and summing across different pollen types for each bee.

\subsubsection{Body size and lipid measurements}

We measured the inter-tegular (IT) span and body lipid content of the same bumble bees that we used for pollen analysis. IT span is the distance between the nearest edges of the tegulae. This is a standard index of bee size and a good estimator of dry body weight (Cane 1987; Bullock 1999; Hagen and Dupont 2013) and foraging range (Greenleaf et al. 2007). A single observer measured IT span in millimeters using digital calipers under a dissecting microscope.

We quantified body lipid content using a Soxhlet apparatus with petroleum ether extraction. This solvent has been used for fat extraction in solitary bees (O'Neill et al. 2015) and wasps (Strohm 2000). Petroleum ether extracts neutral, non-structural lipids which are the stored energy reserves and regularly measured in insects (Williams et al. 2011). We placed individual bees in plastic trays of known weight, dried in a $60^{\circ} \mathrm{C}$ oven, and weighed on an analytical balance. The samples were then crushed in individual filter paper envelopes and loaded into the Soxhlet for $6 \mathrm{~h}$. After lipid extraction, the samples were weighed again. To calculate the mass of lipid per bee, we measured the difference between postextraction dry mass and pre-extraction dry mass. We measured the proportion of fat by taking the absolute fat content and dividing it by the mass of the bee. One outlier of a bee with $40 \%$ fat was removed from analysis, as this bee was likely a queen (since queens have higher fat content), and our study investigated foraging worker bumble bees.

\subsection{Analysis}

All analyses were run in $\mathrm{R}$ ( $\mathrm{R}$ Core Team 2017). To compare the corbicular pollen types collected by bees with floral resources present at each site, we performed three separate Pearson's Chi-squared tests (R package "MASS"), one for each site type: conventional blueberry farms, organic farms, and natural areas. Since pollen types can only be identified to genus or family (species within genera almost never differ in pollen grain morphology), we combined our floral resource data to match the pollen types.

To examine whether the proportion of different pollen types collected differed among our site types, we summed pollen counts by type across all bees within each site type and ran a Pearson's Chi-squared test. To evaluate whether individual bees from the site types differed in the richness of pollen collected, the amount of protein in collected pollen, or their IT span, we used linear mixed effects models ("Ime4," Bates et al. 2015) with site type as a fixed effect and site and bumble bee 
species as random effects. For those models for which there was a significant effect of site type (using ANOVA type III Satterthwaite approximations), we tested how the site types differed using post-hoc Tukey's tests.

To assess which factors had an effect on fat content of bees, we used a linear mixed effects model ("Ime4," Bates et al. 2015) to identify the effects of site type, the richness of pollen types collected, and pollen protein content on fat content, with site and bumble bee species as random effects. We expected that bees foraging in landscapes where they could collect more pollen types or more total protein would have higher fat content. This expectation assumes that the resources available to adult bees are similar to the resources available when they were fed as larvae. We controlled for size of bee in the model by including IT span in the model, as bees of differing sizes are likely to forage over different ranges.

\section{RESULTS}

Blueberry pollen comprised $45 \%$ of total pollen in corbiculae of bumble bees collected on conventional farms, $67 \%$ of pollen from organic farms, and $1 \%$ of pollen from natural areas (Figure 1). Rosaceae pollen from shrubs was also common, comprising $32 \%$ of total pollen in corbiculae of bees from conventional farms, $11 \%$ of pollen from organic farms, and $74 \%$ of pollen from natural areas. This pollen is most likely from salmonberry (Rubus spectabilis ) or trailing blackberry (Rubus ursinus) as they flower during our collection period in May. The pollen types collected by bees were significantly different from the floral resources available at the three site types (conventional: $\chi^{2}=1321.4, P<0.0001$; organic: $\chi^{2}=1204.7, P<0.0001$; natural: $\chi^{2}=825.2$, $P<0.0001$; Figure 1).

Bumble bees from the three different site types differed in the proportion of pollen collected from different plant species $\left(\chi^{2}=123.56, P<0.0001\right.$; Figure 1). Bees from natural areas tended to have higher pollen richness, pollen protein content, and fat content (Table I), but only protein and fat content achieved statistical significance (site type effects on pollen richness: $F=1.28, P=0.31$; pollen protein content: $F=12.29, P=0.0008$; fat content: $F=3.85, P=0.045)$. Pollen protein content in corbicular loads from bees collected from natural areas was higher than from bees from both conventional farms $(z=3.92, P=0.0002)$ and organic farms $(z=4.50, P<0.0001)$, but there was no difference between farm types $(z=$ $-0.64, P=0.52)$. Bees from natural areas had higher mean fat content compared to bees from conventional farms $(z=2.62, P=0.03)$, but not organic farms $(z=1.98, P=0.10)$, and again there was no difference between the two farm types $(z=0.44, P=0.66)$.

Total estimated protein content in pollen loads was not related to fat content of bees $(F=0.41$, $P=0.41)$. There was no significant effect of pollen richness per bee on fat content of these bees either $(F=2.46, P=0.12)$. Although we found no effect of site type on mean IT span $(F=2.26, P=0.14)$, we found a negative relationship between fat content and IT span, with a 3.9\% (SE 1.07) decrease in mean fat content for every mm increase of mean IT $\operatorname{span}\left(R^{2}=0.056, P=0.004\right.$; Figure 2).

\section{DISCUSSION}

Bumble bees preferentially foraged on particular pollen types, and these differed from the floral resources found at the site level. In natural areas, bees collected more pollen from shrub Rosaceae (likely Rubus spp.) and less from tree Rosaceae (could be Amalanchier, Crataegus, Malus, Prunus, or Sorbus spp.) than the relative availability of these resources. Collection of Rosaceae pollen likely indicates that bees may be supplementing their diet with off-farm resources, most likely with native salmonberry (Rubus spectabilis ) or trailing blackberry (Rubus ursinus), neither of which is commonly present on farms. Blueberry flowers present a pulse of floral resources, but our data suggests that they may not be attractive for pollinators, which likely has implications for the pollination of this crop.

Bumble bee foraging strategies for preferred pollen types may be based on nutritional requirements, such as the amount of crude protein found in pollen. The average crude protein content of pollen is between 20 and $25 \%$, and, for honeybees, any pollen source lower than $20 \%$ is considered a low protein pollen, and 


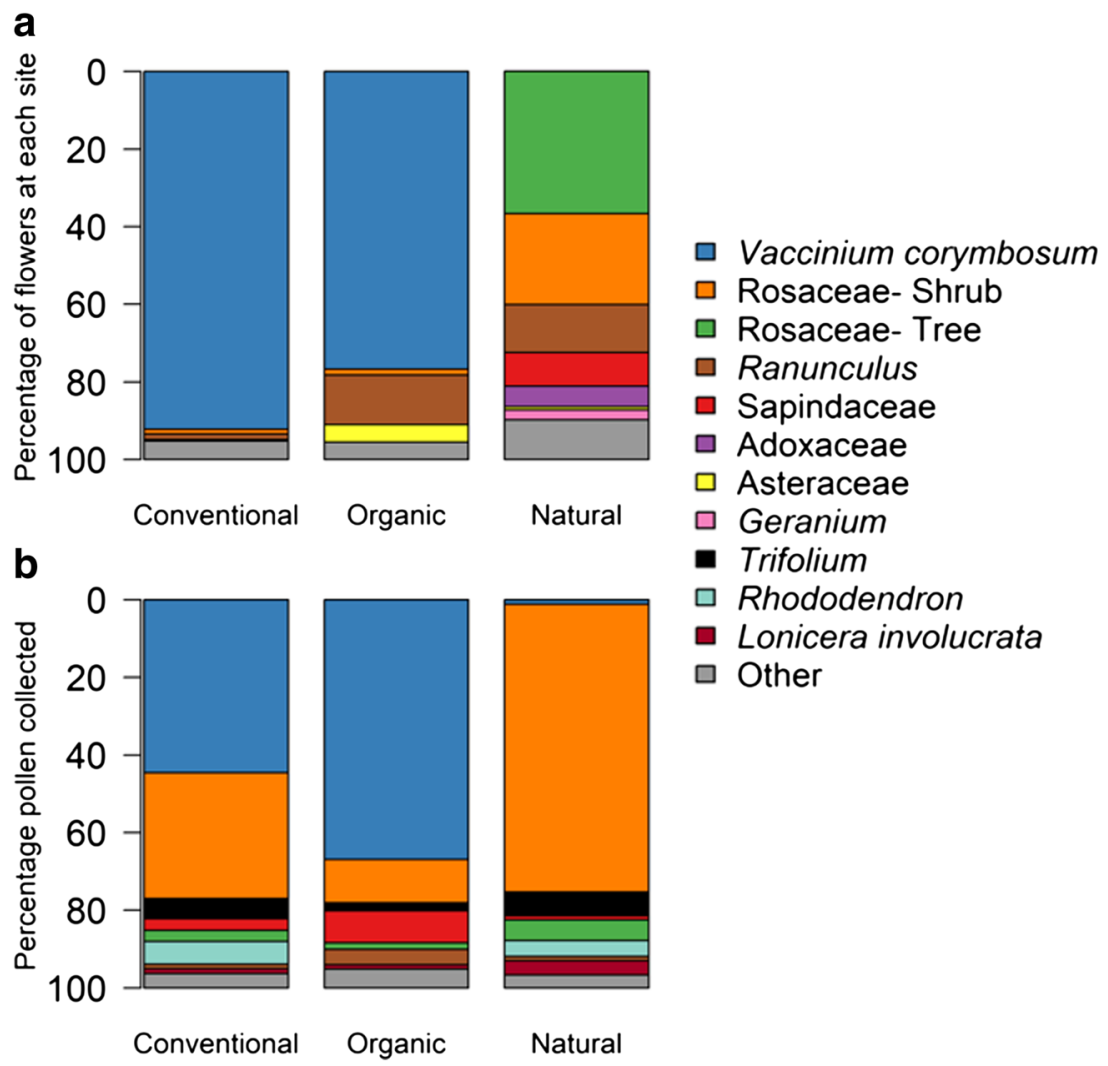

Fig. 1 a Floral resources present at 6 conventional highbush blueberry farms, 6 organic farms, and 6 natural areas in the Fraser River valley, British Columbia. b Pollen collected by bumble bees at the same sites. Corbicular pollen differs significantly from the resources available within each site type. "Other" pollen types comprise less than 5\% of total pollen collected by site type.

any pollen source above $25 \%$ considered above average quality pollen (Somerville 2001). Bumble bees have been shown to prefer higher pollen protein content than honey bees
(Leonhardt and Blüthgen 2012). The lowprotein content of blueberry pollen $(13.9 \%$, Somerville 2001) may be why bumble bees in our study are supplementing their diet with

Table I. Mean and standard error of pollen richness, pollen protein content (\% crude protein), and fat content (\%) of bumble bees from conventional blueberry farms, organic blueberry farms, and natural areas in the lower Fraser River valley, British Columbia.

\begin{tabular}{|c|c|c|c|c|c|c|}
\hline \multirow[t]{2}{*}{ Variable } & \multicolumn{2}{|c|}{ Conventional } & \multicolumn{2}{|c|}{ Organic } & \multicolumn{2}{|c|}{ Natural } \\
\hline & Mean & SE & Mean & $\mathrm{SE}$ & Mean & SE \\
\hline Pollen richness & $2.30^{\mathrm{a}}$ & 0.12 & $2.06^{\mathrm{a}}$ & 0.10 & $2.44^{\mathrm{a}}$ & 0.09 \\
\hline Pollen protein & $17.8^{b}$ & 0.42 & $17.1^{\mathrm{b}}$ & 0.47 & $20.9^{\mathrm{a}}$ & 0.34 \\
\hline Bee fat content & $10.1^{\mathrm{b}}$ & 0.51 & $11.1^{\mathrm{ab}}$ & 0.52 & $11.9^{\mathrm{a}}$ & 0.53 \\
\hline
\end{tabular}

There were six sites for each site type. Sample size for bees: conventional $=81$; organic $=63$; natural $=100$. For each variable, means with the same letter are not significantly different from one another 


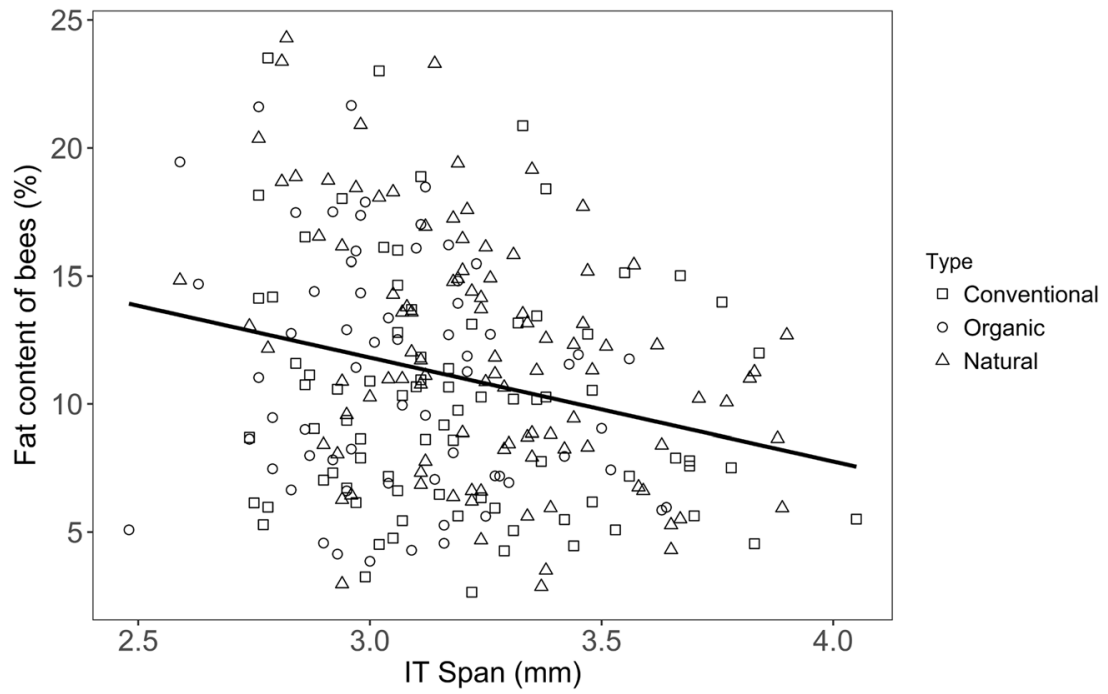

Fig. 2 Fat content decreases with relative worker size (as measured by intertegular (IT) span) in 244 worker bumble bees collected from conventional farms, organic farms, and natural areas in the lower Fraser River valley, British Columbia ( $n=6$ sites per site type).

other pollen types. Our results suggest that bees are modifying their foraging to ensure that they collect high-quality protein. Similar to our results, honey bees in intensively managed farms collected pollen from a diversity of non-crop flowers, related to their nutritional value (Requier et al. 2015).

Natural areas had a greater diversity of floral resources available to bees than either farm type, as expected. Floral resource availability did not translate into differences in the diversity of pollen collected by individual bees, likely because of the well-known tendency for flower constancy in social bees (Waser 1986). However, as predicted, bees from natural areas did have higher fat content than those from conventional farms, with bees from organic farms in between (although not different from either of the other site types). Bees from the two farm types may not have differed because non-crop floral resources were only slightly different between the two farm types. Our findings from natural areas support the idea that resource availability has implications for bee body condition. Bees on farms may be flying further from their nests to forage on preferred pollen sources compared to bees in natural areas, which may reduce their fat content. Given that the fat body is considered a proxy for immunocompetence (Wilson-Rich et al. 2009; Alaux et al. 2010), our finding of decreased fat content of bees on farms may have synergistic effects with stressors, such as the ability for bees to cope with toxins and pathogens (Goulson et al. 2015).

We were surprised by our result of smaller bees having relatively higher fat content. Relative fat content increases with body size for the European beewolf, Philanthus triangulam (Strohm 2000), and we expected a similar relationship in bumble bees. It is possible that smaller bees fly less far (e.g., Greenleaf et al. 2007) and so deplete fat reserves less while foraging. Although pollination effectiveness increases with bumble bee size (Willmer and Finlayson 2014), our results indicate that size may not be reflective of overall body condition of the bee. Other metrics of body condition could be included in future work, including individual hemocyte concentration, or phenoloxidase activity (Alaux et al. 2010; Roger et al. 2017), or if possible colony metrics of fitness such as brood production (Smart et al. 2016) or behavioral responses like larval ejection rate (Roger et al. 2017).

Other considerations besides protein content in pollen could cumulatively represent foraging 
choices of bumble bees, including amino acid composition, lipids, and micronutrients (Vanderplanck et al. 2014; Moerman et al. 2016; Vaudo et al. 2016; Somme et al. 2015). Foraging choices of pollen and assessment of pollen are complex tasks for bees, compared to assessment of sugar content which can be done immediately (Nicholls and de Ibarra 2016). There are 10 essential amino acids required for honey bee nutrition (de Groot 1953), and balancing amino acid ratios is important for both honey bee (Somerville 2005) and bumble bee health (Somme et al. 2015). Besides being low in crude protein content, blueberry pollen is low in the amino acid tryptophan (Somerville and Nicol 2006), which further suggests that blueberry pollen alone is not an adequate resource for bee nutrition. Stoichiometric balancing of elements in pollen can also play a role in pollen selection by bumble bees since limitation of elements may decrease bee growth and development (Filipiak et al. 2017). Our study did not assess the full nutritional profile of bumble bees' preferred pollen sources, and future work could investigate different components of pollen to understand why bees are selectively foraging for particular pollen sources. Future work could also address the issue that even high protein content may not guarantee uptake of that protein by the bee.

Consideration of the nutritional requirements of wild bees is still a relatively new field, and there are two ways that future work could improve on our study. Total crude protein in pollen loads could be measured directly, leading to more accurate estimates than those based on published estimates, but this has only been done in a few cases (Tasei and Aupinel 2008; Somme et al. 2015; Vaudo et al. 2016). Another important consideration for future work is the best proxy for nutritional state. Larvae in colonies of the three species of bumble bees that we collected were presumably fed blueberry pollen. However, the bees that we analyzed for fat content provided an indirect proxy of what is fed to developing larvae, since the pollen that we analyzed would have been fed to the next generation of larvae, not the adult bees we analyzed.

Supplementing floral resources on farms could be beneficial to bees and farmers be- cause bees would forage closer to the farm. Wildflower plantings on farms can increase diversity and abundance of beneficial insects, including wild pollinators (Williams et al. 2015) but also insects providing pest control services (Blaauw and Isaacs 2015). Our pollen analysis lists numerous preferred pollen sources for bumble bees that if provided on farms in our region, might reduce the distance bees need to fly to forage, potentially leading to more foraging time in the crop. However, although we demonstrate a strong foraging preference for shrub Rosaceae pollen in this study, many species within this family produce fleshy fruits which can serve as an alternative host for the invasive Drosophila suzukii in our region. It is therefore recommended by the British Columbia Ministry of Agriculture that these plants be removed from the farm landscape. This highlights a conflict between providing resources for beneficial insects and the costs that arise when those resources are alternative hosts for pests. We therefore suggest that on-farm habitat enhancements could benefit from planting non-invasive garden plants that provide high nutritional value for bees but which are not attractive to pests.

Our results show that both the protein in corbicular pollen loads and the fat content of bees are higher in natural areas that have greater plant diversity than are found on farms. Although organic farms tend to have more non-crop resources than conventional farms, this did not translate into differences in bee fat content between farm types. We suggest that there is likely a benefit to a diversity of pollen sources available to bees, whether through wildflower enhancements on farms or through the preservation of natural landscapes adjacent to farm landscapes.

\section{ACKNOWLEDGEMENTS}

T. Haapalainen provided field assistance, and T. Williams, A. Cornell, and J. Yap assisted with lipid extraction protocols. Multiple farmers, the City of Abbotsford, and the Metro Vancouver Regional Parks provided site access. 


\section{AUTHOR CONTRIBUTION}

MT and EE conceived this research and designed the experiments. MT performed the research and analyzed the data with input from EE. MT wrote the paper, and EE participated in the revisions. Both authors read and approved the final manuscript.

\section{FUNDING INFORMATION}

Funding was provided by the Natural Sciences and Engineering Research Council of Canada (grant to EE), the USDA-NIFA Specialty Crop Research Initiative Grant (\#2012-51181-20105) to the Integrated Crop Pollination Project, and the Northwest Scientific Association (grant to MT).

\section{COMPLIANCE WITH ETHICAL STANDARDS}

Conflict of interest The authors declare that they have no potential conflict of interest in relation to the study in this paper.

Préférences de recherche de nourriture des bourdons sauvages et teneur en matières grasses dans les agroécosystèmes de myrtilles

Bombus / analyse du pollen / pollinisateur / Vaccinium corymbosum

Sammelpräferenz von wilden Hummeln und Fettgehalt in hochbuschigen Heidelbeeren Ökosystemen

\section{Bombus / Pollenanalyse / Bestäuber / Vaccinium corymbosum}

\section{REFERENCES}

Aizen, M. A. and Feinsinger, P., (2003) Bees not to be? Responses of insect pollinator faunas and flower pollination to habitat fragmentation. Pages 111-129 in G. A. Bradshaw and P.A. Marquet, editors. How landscapes change. Springer-Verlag Berlin, Germany.

Alaux, C., Ducloz, F., Crauser, D. and Le Conte, Y., (2010) Diet effects on honeybee immunocompetence. Biol. Lett. 6, 562-565.
Amdam, G.V. and Omholt, S.W., (2002) The regulatory anatomy of honeybee lifespan. J. Theor. Biol. 216, 209-28.

Arrese, E.L. and Soulages, J.L., (2010) Insect fat body: energy, metabolism, and regulation. Annu. Rev. Entomol. 55, 207-225.

Bates, D., Maechler, M., Bolker, B.M. and Walker, S., (2015) Fitting linear mixed-effects models using lme4. J. Stat. Softw. 67, 1-48.

Blaauw, B.R. and Isaacs, R., (2015) Wildflower plantings enhance the abundance of natural enemies in adjacent blueberry fields. Biol Control 91, 94-103.

Bobiwash, K., Uriel, Y. and Elle, E., (2018) Pollen foraging differences among three managed pollinators in the highbush blueberry (Vaccinium corymbosum) agroecosystem. J. Econ. Entomol. 111, 26-32.

Bullock, S.H., (1999) Relationships among body size , wing size and mass in bees from a tropical dry forest in México. J. Kansas Entomol. Soc. 72, 426-439.

Button, L. and Elle, E., (2014) Wild bumble bees reduce pollination deficits in a crop mostly visited by managed honey bees. Agric. Ecosyst. Environ. 197, 255-263.

Cane, J.H., (1987) Estimation of bee size using intertegular span (Apoidea). J. Kansas Entomol. Soc. 60, 145-147.

Couvillon, M. J., R. Schurch, and F. L. W. Ratnieks., (2014). Waggle dance distances as integrative indicators of seasonal foraging challenges. PLoS ONE 9:7.

Crompton, C.W. and Wojtas, W.A., (1993) Pollen Grains of Canadian Honey Plants. Ottawa: Agriculture Canada.

Cunningham, S.A., (2000) Depressed pollination in habitat fragments causes low fruit set. Proc. R. Soc. Lond. B Biol. Sci. 267, 1149-1152.

de Groot, A.P., (1953) Protein and amino acid requirements of the honey bee (Apis mellifera L.). Lab. Comp. Physiol. 3, 197-285.

Defries, R.S., Foley, J.A. and Asner, G.P., (2004) Land-use choices : balancing human needs and ecosystem function in a nutshell. Front. Ecol. Environ.. 2 , 249-257.

Filipiak, M., Kuszewska, K., Asselman, M., Stawiarz, E., Woyciechowski, M. and Weiner, J., (2017) Ecological stoichiometry of the honeybee: pollen diversity and adequate species composition are needed to mitigate limitations imposed on the growth and development of bees by pollen quality. PLoS One 12, e0183236.

Foley, J.A., Defries, R., Asner, G.P., Barford, C., Bonan, G., Carpenter, S.R., Chapin, F.S., Coe, M.T., Daily, G.C., Gibbs, H.K., Helkowski, J.H., Holloway, T., Howard, E.A., Kucharik, C.J., Monfreda, C., Patz, J.A., Prentice, I.C., Ramankutty, N. and Snyder, P.K., (2005) Global consequences of land use. Science 309, 570-575.

Gabriel, D., Sait, S.M., Kunin, W.E. and Benton, T.G., (2013) Food production vs. biodiversity: comparing organic and conventional agriculture. J. Appl. Ecol. 50, 355-364.

Girard, M., Chagnon, M. and Fourniera, V., (2012) Pollen diversity collected by honey bees in the vicinity of Vaccinium spp. crops and its importance for colony developement. Botany 90 , 545-555. 
Goulson, D., Hughes, W.O.H., Derwent, L.C. and Stout, J.C., (2001) Colony growth of the bumblebee, Bombus terrestris, in improved and conventional agricultural and suburban habitats. Oecologia 130, 267-273.

Goulson, D., Nicholls, E., Botías, C. and Rotheray, E.L., (2015) Bee declines driven by combined stress from parasites, pesticides, and lack of flowers. Science 347, 1-16.

Greenleaf, S.S., Williams, N.M., Winfree, R. and Kremen, C., (2007) Bee foraging ranges and their relationship to body size. Oecologia 153, 589-96.

Hagen, M. and Dupont, Y.L., (2013) Inter-tegular span and head width as estimators of fresh and dry body mass in bumblebees (Bombus spp.). Insect. Soc. 60, 251-257.

Haydak, M.H. (1970) Honey bee nutrition. Annu. Rev. Entomol. 15, 143-156.

Hodges, D., (1952) The pollen loads of the honeybee : a guide to their identification by colour and form. Bee Research Association, University of Minnesota.

Kearns, C. A. and Inouye, D. W., (1993) Techniques for pollination biologists. University Press of Colorado, Niwot.

Klein, A.M., Steffan-Dewenter, I., Buchori, D. and Tscharntke, T., (2002) Effects of land-use intensity in tropical agroforestry systems on coffee flowervisiting and trap-nesting bees and wasps. Conserv Biol. 16, 1003-1014.

Klein, A.M., Steffan-Dewenter, I. and Tscharntke, T., (2003) Pollination of Coffea canephora in relation to local and regional agroforestry management. J Appl Ecol. 40, 837-845.

Kremen, C., Williams, N.M. and Thorp, R.W., (2002) Crop pollination from native bees at risk from agricultural intensification. Proc Natl Acad Sci U S A 99, 1681216816.

Leonhardt, S. D. and Blüthgen N. 2012. The same, but different: pollen foraging in honeybee and bumblebee colonies. Apidologie 43, 449-464

Moerman R., Roger N., De Jonghe R., Michez D., and Vanderplanck M. 2016. Interspecific variation in bumblebee performance on pollen diet: new insights for mitigation strategies. PLoS One 11, e0168462.

Morandin, L.A. and Winston, M.L., (2005) Wild bee abundance and seed production in conventional, organic, and genetically modified canola. Ecol. Appl. 15, 871-881.

Naug, D., (2009) Nutritional stress due to habitat loss may explain recent honeybee colony collapses. Biol Cons 142, 2369-2372.

Nicholls, E. and de Ibarra, N.H. (2016) Assessment of pollen rewards by foraging bees. Funct. Ecol. 31, 76-87

Nicolson, S.W. and Human, H., (2013) Chemical composition of the 'low quality' pollen of sunflower (Helianthus annuus, Asteraceae). Apidologie 44, 144-152.

Norton, L., Johnson, P., Joys, A., Stuart, R., Chamberlain, D., Feber, R., Firbank, L., Manley, W., Wolfe, M., Hart, B., Mathews, F., Macdonald, D. and Fuller, R.J., (2009) Consequences of organic and non- organic farming practices for field, farm and landscape complexity. Agric. Ecosyst. Environ. 129, 221-227.

O’Neill, K.M., Delphia, C.M. and Pitts-Singer, T.L., (2015) Seasonal trends in the condition of nesting females of a solitary bee: wing wear, lipid content, and oocyte size. PeerJ 3, e930.

R Core Team (2017) R: A Language and Environment for Statistical Computing. https:/www.R-project.org/

Requier, F., Odoux, J.-F., Tamic, T., Moreau, N., Henry, M., Decourtye, A. and Bretagnolle, V., (2015) Honey bee diet in intensive farmland habitats reveals an unexpectedly high flower richness and a major role of weeds. Ecol. Appl. 25, 881-890.

Ricketts, T.H., (2004) Tropical forest fragments enhance pollinator activity in nearby coffee crops. Conserv Biol 18, 1262-1271.

Roger, N., Michez, D., Wattiez, R., Sheridan, C., and Vanderplanck, M. (2017). Diet effects on bumblebee health. J. Insect Physiol. 96, 128-13.

Roulston, T.H. and Cane, J.H., (2000) Pollen nutritional content and digestibility for animals. Plant Syst. Evol. 222, 187-209.

Sidhu, C.S. and Joshi, N.K., (2016) Establishing wildflower pollinator habitats in agricultural farmland to provide multiple ecosystem services. Front. Plant Sci. 7, 1-5.

Smart, M., Pettis, J., Rice, N., Browning, Z. and Spivak, M., (2016) Linking measures of colony and individual honey bee health to survival among apiaries exposed to varying agricultural land use. PLoS One 11, 1-28.

Somerville, D.C., (2001) Nutritional value of bee collected pollens. Project number DAN.134A.' (Rural Industries Research and Development Corporation: Canberra). NSW Agric. 1-166.

Somerville, D., (2005) Fat bees skinny bees. A manual on honey bee nutrition for beekeepers. Aust. Gov. Rural Ind. Res. Dev. Corp., Goulburn, 1-142.

Somerville, D. and Nicol, H.I., (2006) Crude protein and amino acid composition of honey bee-collected pollen pellets from south-east Australia and a note on laboratory disparity. Aust. J. Exp. Agric. 46, 141-149.

Somme, L., Vanderplanck, M., Michez, D., Lombaerde, I., Moerman, R., Wathelet, B., Wattiez, R., Lognay, G. and Jacquemart, A., (2015) Pollen and nectar quality drive the major and minor floral choices of bumble bees. Apidologie 46, 92-106.

Steffan-Dewenter, I., Münzenberg, U., Bürger, C., Thies, C. and Tscharntke, T., (2002) Scale-dependent effects of landscape context on three pollinator guilds. Ecology $83,1421-1432$.

Strohm, E., (2000) Factors affecting body size and fat content in a digger wasp. Oecologia 123, 184-191.

Tasei, J.-N. and Aupinel, P., (2008) Nutritive value of 15 single pollens and pollen mixes tested on larvae produced by bumblebee workers (Bombus terrestris, Hymenoptera: Apidae). Apidologie 39, 397-409.

Tilman, D., Fargione, J., Wolff, B., Antonio, C.D., Dobson, A., Howarth, R., Schindler, D., Schlesinger, W.H., Simberloff, D., Tilman, D., Fargione, J., Wolff, B., 
Antonio, C.D., Dobson, A., Howarth, R., Schindler, D., Schlesinger, W.H., Simberloff, D. and Swackhamer, D., (2001) Forecasting agriculturally driven global environmental change. Science 292 , 281-284.

Toshack, M. C. (2018). Effects of farming practices and landscape composition on wild invertebrate pollinator and bird abundance, richness, and health. MSc thesis, Simon Fraser University.

Vanderplanck, M., Moerman, R., Rasmont, P., Lognay, G., Wathelet, B., Wattiez, R., and Michez, D. 2014. How does pollen chemistry impact development and feeding behaviour of polylectic bees? PLoS One 9, e86209.

Vaudo, A.D., Patch, H.M., Mortensen, D.A., Tooker, J.F. and Grozinger, C.M., (2016) Macronutrient ratios in pollen shape bumble bee (Bombus impatiens) foraging strategies and floral preferences. Proc. Natl. Acad. Sci. 113 , E4035-E4042.

Walther-Hellwig, K. and Frankl, R., (2000) Foraging habitats and foraging distances of bumblebees, Bombus spp. (Hymenoptera, Apidae), in an agricultural landscape. J. Appl. Entomol. 124, 299-306.

Waser, N.M., (1986) Flower constancy: definition, cause, and measurement. Am. Nat. 127, 593-603.

Westrich P. and Schmidt K., (1986) Methoden und Anwendungsgebiete der Pollenanalyse bei Wildbienen (Hymenoptera, Apoidea). Linzer Biol Beitr 18, 341360 .
Westphal C, Steffan-Dewenter I, and Tscharntke T., (2003) Mass flowering crops enhance pollinator densities at a landscape scale. Ecol. Lett. 6 ,961-965.

Williams, C.M., Thomas, R.H., MacMillan, H.A., Marshall, K.E. and Sinclair, B.J., (2011) Triacylglyceride measurement in small quantities of homogenised insect tissue: comparisons and caveats. J. Insect Physiol. 57, 1602-1613.

Williams, N.M., Ward, K.L., Pope, N., Isaacs, R., Wilson, J.K., May, E., Ellis, J., Daniels, J., Pence, A., Ullmann, K. and Peters, J., (2015) Native wildflower plantings support wild bee abundance and diversity in agricultural landscapes across the United States. Ecol. Appl. 25, 2119-2131.

Willmer, P.G. and Finlayson, K., (2014) Big bees do a better job: intraspecific size variation influences pollination effectiveness. J. Pollinat. Ecol. 14, 244-254.

Wilson-Rich, N., Dres, S.T. and Starks, P.T., (2009) The ontogeny of immunity: development of innate immune strength in the honey bee (Apis mellifera). J. Insect Physiol. 54, 1392-9.

Publisher's note Springer Nature remains neutral with regard to jurisdictional claims in published maps and institutional affiliations. 